\title{
Bacteriological Study of Wound Infections and Their Antibiogram Pattern at A Tertiary Care Hospital in Suburban Area of Hyderabad
}

\author{
Upasana Bhumbla ${ }^{1 *}$, LubnaBandey ${ }^{2}$, Safaa Muneer Ahmad ${ }^{2}$ and Gyaneshwari ${ }^{2}$ \\ ${ }^{1}$ Dept. Of Microbiology, Getanjali Medical College \& Hospital, Udaipur, India \\ ${ }^{2}$ Dept. Of Microbiology, Shadan Institute of Medical Sciences, Udaipur, India
}

\begin{abstract}
Background: Wound infections can be caused through two major sources: exogenous and endogenous bacteria. The probability of wound infection largely depends on the patient's systemic host defenses, local wound conditions and microbial burden. Despite modern surgical techniques and the use of antibiotic prophylaxis, Surgical Site Infection (SSI) is one of the most common complications encountered in surgery. SSI places a significant burden on both the patient and health system. SSI is thus a major cause of morbidity, prolonged hospital stays and increased health costs.

Methods: Two wound swabs were collected from the wound and from a drop of aspirate, smear was made on clean glass slide and Gram staining was done for direct microscopic examination under oil immersion 100X objective to know various morphological types of bacteria and presence or absence of inflammatory cells. Second swab/drop of aspirate was used for culture by inoculating it on routine media like Blood Agar, Nutrient Agar and MacConkey's agar, incubated at $37^{\circ} \mathrm{C}$ for $24 \mathrm{hrs}$. aerobically.

Result: Out of 108 pus samples, 101(88.5\%) were culture positive for bacterial growth and no growth was observed in $7(11.4 \%)$ cases. Out of 101 bacterial culture positive cases, 96 were nonbacterial and 5 were poly bacterial. Out of 96 bacterial isolates; S. aureus (38/36.6\%) was the commonest followed by P. aeruginosa $(26 / 24.7 \%)$
\end{abstract}

Conclusion: The study concludes that variety of aerobic bacteria is responsible for wound infection with predominance of Staphylococcus aureus followed by Pseudomonas aeruginosa

Keywords: Staphylococcus Aureus, Pseudomonas Aeruginosa, Nonbacterial

\section{Introduction}

Infection is defined as invasion and multiplication of micro organisms in the body tissues, which may be clinically in apparent or result in local cellular injury because of competitive metabolism, toxins, intra-cellular replication or antigen antibody response ${ }^{[1]}$. This series of events lead to progressive tissue destruction and eventual host demise if left unchecked. The infection process begins with a disruption of the host mechanical barriers to micro organisms, the availability of microorganisms and

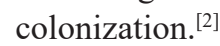

Wound infections can be caused through two major sources: exogenous and endogenous bacteria. The probability of wound infection largely depends on the patients systemic host defenses, local wound conditions and microbial burden ${ }^{[3,4]}$.Despite modern surgical techniques and the use of antibiotic prophylaxis, Surgical Site Infection (SSI) is one of the most common complications encountered in surgery ${ }^{[5]}$. SSI places a significant burden on both the patient and health system. SSI is thus a major cause of morbidity, prolonged hospital stay and increased health costs ${ }^{[6] \text {. }}$

Skin and soft tissue infections (SSTIs) may also contribute to longer hospital stays increase the cost of medical care and play an important role in development of antimicrobial drug resistance. Common examples of SSTIs includes cellulitis, abscesses, impetigo, folliculitis, furuncle, carbuncle, necrotizing fasciitis, diabetic foot infections and surgical site infections. Complicated SSTI may prove fatal and require hospitalization, intravenous antibiotics or surgery. An SSTI is classified as complicated if the infection has spread to the deeper soft tissue, if surgical intervention is necessary or if the patient has co-morbid conditions Hence, this study could play a significant role in the early recognition of the

Problem and hence, there is need for early intervention for better management of wound infections.

AIM \& OBJECTIVES 1 . To isolate and identity the aerobic bacterial pathogens from wound infections., 2 . 
To determine the antibiotics susceptibility pattern of the isolated pathogens with special reference to Methicillin resistant Staphylococcus aureus (M R S A) and Extended spectrum of $\beta$-lactamases (E S B L). \& 3. To find out the incidence of aerobic bacterial pathogens in infected wounds.

\section{Material and Methods}

Two wound swabs were collected from the wound and from a drop of aspirate, smear was made on clean glass slide and Gram staining was done for direct microscopic examination under oil immersion $100 \mathrm{X}$ objective to know various morphological types of bacteria and presence or absence of inflammatory cells. Second swab/drop of aspirate was used for culture by inoculating it on routine media like Blood Agar, Nutrient Agar and MacConkey's agar, incubated at $37^{\circ} \mathrm{C}$ for 24 hrs. ${ }^{[7-9]}$ aerobically. The plates were examined the next day for growth. Plates not showing any growth were further incubated at $37^{\circ} \mathrm{C}$ aerobically for another 24 hrs. Plates not showing any growth after $48 \mathrm{hrs}$ on aerobic incubation were considered to be lacking aerobic bacterial pathogens. Smears were made, stained by Gram stain and examined under oil immersion microscope 100X objective.

Antibiotic sensitivity testing was performed on Mueller Hinton Agar according to CLSI guidelines. MRSA was detected using Cefoxitin (30ug) disc and ESBL production in Gram negative bacteria was detected by using Potentiated Disc Diffusion Test (PDT) ${ }^{[8-10]}$

Exclusion Criteria: Patients already on antibiotics were excluded from the study

\section{Results}

One hundred \& eight cases of wound infections were taken to isolate and identify the aerobic bacterial pathogens from various departments like Surgery, Gynecology \& Orthopedics. Surgical wound swabs were 39 (36.11\%) and
Non Surgical wound swabs were $69(63.89 \%)$ in number.

Out of 69 Non-surgical wounds, $46(66.5 \%)$ were soft tissue infections wound and burn wounds, and 23(33.55\%) were traumatic wounds. Out of 39 surgical wounds, 21(54.9\%) were post-operative wounds and $18(45.5 \%)$ were surgical site infection wounds.

Pus discharge was collected from 108 patients were identified, out of which $67(59.1 \%)$ were males and 43(40.9\%) were females. Age ranged from 10 months to 65 years with maximum number of cases seen between the age group of $21-40$ years $(62.3 \%)$ as shown in Table 1. Cases of pus discharge came mainly from rural areas (92 $/ 85.32 \%$ ) as compared to urban areas (16/14.68\%).

Bacterial Isolates: Out of 108 pus samples, 101(88.5\%) were culture positive for bacterial growth and no growth was observed in 7(11.4\%) cases as shown in Table 2. Out of 101 bacterial culture positive cases, 96 were monobacterial and 5 were poly bacterial. .Out of 96 bacterial isolates; S. aureus $(38 / 36.6 \%)$ was the commonest followed by $P$. aeruginosa $(26 / 24.7 \%)$

The prevalence of monomicrobial isolates from various wound infections is depicted in table 3, wherein Staphylococcus aureus was the predominant organism when samples were collected from post operative wounds, burns, traumatic wounds and soft tissue infections.

Antibacterial Susceptibility Profile: Gram positive bacteria showed maximum susceptibility to Vancomycin and Amikacin whereas gram negative isolates showed maximum susceptibility to Imipenem and Amikacin. $P$. aeruginosa isolates showed maximum susceptibility to Imipenem and Ceftriaxone. $31.4 \%$ of S.aureus isolates were MRSA and 36\% of Gram negative isolates were ESBL producers as shown in Table 4.

Table 1: Age and Sex Distribution of Wound Infections.

\begin{tabular}{|c|c|c|c|c|c|c|}
\hline \multirow{2}{*}{ Age group } & \multicolumn{2}{|c|}{ Male } & \multicolumn{2}{|c|}{ Female } & \multirow{2}{*}{$\begin{array}{l}\text { Total ( no. of } \\
\text { cases) }\end{array}$} & \multirow{2}{*}{$\begin{array}{l}\text { Percentage \% } \\
\quad(n=108)\end{array}$} \\
\hline & No. of cases & $\%$ age & No. of cases & $\%$ age & & \\
\hline $0-20$ & 11 & 17.83 & 06 & 14.73 & 17 & 15.7 \\
\hline $21-40$ & 37 & 55.41 & 30 & 72.63 & 67 & 62.3 \\
\hline $41-60$ & 16 & 22.29 & 04 & 10.52 & 20 & 18.5 \\
\hline Above 60 & 03 & 4.45 & 01 & 2.1 & 04 & 3.7 \\
\hline Total & 67 & 100 & 41 & 100 & 108 & 100 \\
\hline
\end{tabular}

Table 2: Distribution Pattern of Bacterial Isolates $(n=108)$.

\section{Organisms \\ Staphylococcus aureus}

Total No. of cases

35 


\begin{tabular}{|l|l|}
\hline Organisms & Total No. of cases \\
\hline Pseudomonas aeruginosa & 11 \\
\hline Escherichia coli & 07 \\
\hline Klebsiella pneumoniae & 05 \\
\hline Proteus mirabilis & 04 \\
\hline Acinetobacter spp. & 05 \\
\hline Coagulase negative Staphylococci & 04 \\
\hline Enterococcus fecalis & 02 \\
\hline Citrobacter freundii & 02 \\
\hline P.aeruginosa + S.aureus & 01 \\
\hline P. aeruginosa +K.pneumoniae & 01 \\
\hline S. aureus + P. mirabilis & 01 \\
\hline K. pneumoniae + P. mirabilis & 07 \\
\hline No growth & 04 \\
\hline
\end{tabular}

Table 3: Monomicrobial isolates in various wound infections.

\begin{tabular}{|c|c|c|c|c|c|c|c|c|c|}
\hline $\begin{array}{l}\text { Types of } \\
\text { wounds }\end{array}$ & S.aureus & P.aeruginosa & E.coli & K.pneumoniae & P.mirabilis & $\begin{array}{c}\text { Acinetobacter } \\
\text { spp. }\end{array}$ & CONS & E.fecalis & C.freundii \\
\hline \begin{tabular}{|l} 
Post \\
operative \\
wounds \\
\end{tabular} & 9 & 7 & 5 & 5 & 2 & 2 & - & 2 & 1 \\
\hline Burns & 5 & 13 & 2 & 1 & 2 & 1 & 4 & 1 & - \\
\hline Traumatic & 11 & 3 & 3 & 1 & 1 & 1 & - & 1 & 1 \\
\hline $\begin{array}{l}\text { Soft tissue } \\
\text { infections }\end{array}$ & 10 & - & 1 & - & - & - & 1 & - & - \\
\hline \multirow[t]{2}{*}{ Total } & 35 & 23 & 11 & 7 & 5 & 4 & 5 & 4 & 2 \\
\hline & $36.4 \%$ & $23.9 \%$ & $11.4 \%$ & $7.2 \%$ & $5.2 \%$ & $4.1 \%$ & $5.2 \%$ & $4.1 \%$ & $2 \%$ \\
\hline
\end{tabular}

Table 4: Antibiotic Sensitivity Pattern of Bacterial Isolates.

\begin{tabular}{|c|c|c|c|}
\hline Antibiotics & $\begin{array}{c}\text { Gram positive isolates } n \\
=44\end{array}$ & $\begin{array}{c}\text { Gram negative isolates } n \\
=25\end{array}$ & $\begin{array}{l}\text { Pseudomonas isolates } \\
\qquad n=23\end{array}$ \\
\hline Vancomycin (VA) & $100 \%$ & - & \\
\hline Clindamycin (CD) & $26.5 \%$ & - & \\
\hline Linezolid (LZ) & $76.5 \%$ & - & \\
\hline Erythromycin (E) & $55.9 \%$ & - & \\
\hline Ampicillin (AMP) & $61.8 \%$ & - & \\
\hline Amoxyclav (AMC) & $52.9 \%$ & - & \\
\hline Ceftriaxone (CTR) & $73.5 \%$ & $55.6 \%$ & $72 \%$ \\
\hline Cefoxitin (CX) & $70.6 \%$ & - & \\
\hline Cefotaxime (CTX) & - & $44.4 \%$ & \\
\hline Ceftazidime (CAZ) & - & $38.9 \%$ & $61.1 \%$ \\
\hline
\end{tabular}




\begin{tabular}{|l|c|c|c|}
\hline Antibiotics & $\begin{array}{c}\text { Gram positive isolates n } \\
\mathbf{4} 44\end{array}$ & $\begin{array}{c}\text { Gram negative isolates n } \\
\mathbf{2} 25\end{array}$ & $\begin{array}{c}\text { Pseudomonas isolates } \\
\mathbf{n = 2 3}\end{array}$ \\
\hline Gentamicin (GEN) & $41.2 \%$ & $38.9 \%$ & $33.3 \%$ \\
\hline Amikacin (AK) & $82.4 \%$ & $72.2 \%$ & $69.4 \%$ \\
\hline Imipenem (IPM) & - & $94.4 \%$ & $86.1 \%$ \\
\hline Piperacillin + Tazobactum (TZP) & - & $66.7 \%$ & $66.7 \%$ \\
\hline Cefopodoxime (CPZ) & - & $50 \%$ & $36.1 \%$ \\
\hline Ciprofloxacin (CIP) & - & $33.3 \%$ & $44.4 \%$ \\
\hline Netlimicin (NET) & $31.4 \%$ & - & - \\
\hline MRSA & - & $36 \%$ & \\
\hline ESBL producers & - & - & \\
\hline
\end{tabular}

\section{Discussion}

In the present study an attempt was made to study the bacteriological profile of wound infections and antimicrobial susceptibility pattern of the isolates. In this study along with the identification of aerobic bacterial organisms, changing pattern of antibiotic sensitivity with special reference to Methicillin Resistant Staphylococcus aureus (MRSA) and Extended Spectrum of Beta lactams (ESBLs) were also Identified.

It was observed that the commonest age group affected is 21-40 years which is correlated with the studies done by Shute Malik et al ${ }^{[11]}$ and Dr. Zarrin Afroz et al ${ }^{[12]}$. Males $(63.4 \%)$ were affected more than females $(36.6 \%)$. This study was correlated with Ramesh Rao et al ${ }^{[13]}$ which showed males $(60 \%)$ more affected than females, $\mathrm{N}$. Sowmya et al ${ }^{[14]} 66.6 \%$ and Shruti Malik et al ${ }^{[11]} 51.9 \%$ also showed the predominance of males over females probably because of their more exposure to life.

Monomicrobial etiology was more common $88.8 \%$, than polymicrobial $4.6 \%$. This study is correlated with $\mathrm{N}$. Soumya et al ${ }^{[14]} 91.7 \%$ and Mehta V.J. et al ${ }^{[15]} 70.4 \%$ wherein the monomicrobial etiology was more common than polymicrobial which may be due to the prior use of antibiotics.

In the present study Staphylococcus aureus $32.4 \%$ was the predominant organism followed by Pseudomonas aeruginosa $21.2 \%$, Escherichia coli 10.1\%, Klebsiella pneumoniae $6.4 \%$, Proteus mirabilis $4.6 \%$ and CONS $4.6 \%$. Staphylococcus aureus (32.4\%) was the most predominant isolate which correlated with the other studies done Shruti Malik (30.1\%), Mehta V.J. (38.3\%), Ramesh Rao (27.8\%) and Dr. Pravin (48.4\%). ${ }^{[13-16]}$

Second most predominant organism in the present study was Pseudomonas aeruginosa 21.2\% which correlated with the studies of Gayathree Naik (20\%), Shruti Malik (17.8\%), Mehta V.J (21.3\%), Ramesh Rao (18.5\%) and Dr. Pravin $(17.52 \%) .{ }^{[11-15]}$

In the present study, polymicrobial 5 cases included combination of Pseudomonas aeruginosa with Staphylococcus aureus (40\%) which correlates with the study of Anbumani et al. Other polymicrobials included Pseudononas aeruginosa with Klebsiella pneumonia accounting for $20 \%$ cases, Klebsiella pneumonia with Proteus mirabilis 20\% and Staphylococcus aureus with Proteus mirabilis $20 \%$ case.

Out of 35 Staphylococus aureus isolates, 11(31.42\%) were MRSA producers and remaining 24 (68.5\%) were MSSA producers. The present study correlates with the study of Rajaduraipandi et al ${ }^{[17]}$ with $31 \%$, Anupurba et al ${ }^{[18]}$ with $32 \%$ and N. Soumya et al ${ }^{[14]}$ with $27.5 \%$, as MRSA producers. Among 25 Enterobactericeae isolates, $9(36 \%)$ were ESBL producers and $16(64 \%)$ were NonESBL producers which correlated with the studies done by Mehta V.J ${ }^{[15]}$ with $44.6 \%$, K Rajaduraipandi et al ${ }^{[19]}$ with $40 \%$ and Anupurba $\mathrm{S}$ et al ${ }^{[20]}$ with $41.2 \%$ as ESBL producers respectively.

In the present study Vancomycin (100\%) was the most sensitive antibiotic among all gram positive isolates which was correlated with the studies of Amrita Shriyan et al ${ }^{[21]}$, Shahnooshi Javed et al ${ }^{[22]}$ and Jeena Amatya et al ${ }^{[23]}$. Amikacin was the second most sensitive antibiotic to many gram positive as well as gram negative isolates accounting for $83.5 \%$, which is correlated with the study of Amrita Shriyan et al ${ }^{[21]} 95 \%$ and Shruti Malik et al [11] $90 \%$. Imipenem was the most sensitive drug among gram negative isolates accounting for $93.1 \%$ which was correlating with the study of Shruti Malik et al ${ }^{[11]}$, Amrita Shriyan et al ${ }^{[21]}$ and Ramesh Rao et al ${ }^{[13]}$. Second most common sensitive drug was Amikacin 79.8\% which was 
correlated with the study of Shruti Malik et al, Ramesh Rao et al, Jeena Amutya et al and Rai $\mathrm{S}$ et al. ${ }^{[11,13,23,24]}$

\section{Conclusion}

Wound infections are one of the most common hospital acquired infections, and are an important cause of morbidity \& account for $70-80 \%$ mortality. Development of such infections represent delayed healing, cause anxiety \& discomfort for patient, longer stays at hospitals \& add to cost of healthcare services significantly. The incidence of multi drug resistant pathogens as a cause of wound infection is rising. Here lies the importance of formulating an institutional antimicrobial policy based on local microbiological data.

This study was carried out to determine the antibacterial susceptibility of bacteria isolated from wound infections as well as update the clinicians in the various antimicrobial alternatives available in the treatment of wound infections, thus helping to reduce the burden of infection on patients and in long term, it may reduce the cost of treatment. The study concludes that variety of aerobic bacteria is responsible for wound infection with predominance of Staphylococcus aureus followed by Pseudomonas aeruginosa.Antibiotic sensitivity pattern of the study revealed that Amikacin was the most sensitive drug among both gram positive and gram negative isolates. Imipenem was the most sensitive drug among all gram negative isolates and Vancomycin was the most sensitive drug among gram positive isolates.

More comprehensive studies are required from time to time to define the magnitude of problem \& produce data for policy decision on optimal intervention modalities.

\section{References}

1. McGeer A, Campbell B, Emori TG et al. Definitions of infection for surveillance in long term care facilities Am J. Infect Control 1991 Feb; 19(1): 1-7.

2. Patricia Tille Text book of Diagnostic Microbiology, Bailey and Scott's. Thirteenth Edition Pg 961-970.

3. Lauwers S, F De Smet, Surgical Site Infections Acta Clinica Belgica 1998, 53-5; 303-310.

4. Culbertson WR, Altemeier WA, Gonzalez LC, Hill EO. Studies on the epidemiology of the post - operative infection of clean operative wounds, Ann Surg 1961, 154(4):599-603.

5. M Olson, MO' Connor, ML Schwartz. Surgical wound infections. of 5 year prospective study of 20, 193 wounds at Minneapolis Va Medical Centre. Ann Surg, 1984 Mar; 199(3): 253-259.

6. Dellinger, E.P in Sabiston, D.C, Lyerly, K. (Eds) Textbook of Surgery, 18th Edn. WB Saunders Company, Philladilphia, PP-264-280.
7. Forber BA, Salm DF, Weissfiled Diagnostic Microbiology. In Bailey and Scott's, 13th edition; Missiouri, Mosby Elsevier, 1998.

8. Washington CW, Stephen DA, William M, Elmer WK et al. In Koneman's Colour atlas and text book of microbiology. 6th edition; Philadelphia; Lippincotts Williams and Walkins' 2006 ; 68-74.

9. Clinical and Laboratory Standard Institute, Performance Standards for antimicrobial susceptibility testing, twenty third informational supplement, M100-S24, January 2017 Vol 34, No.P:50-57.

10. Miles RS, Anyes SGB. Laboratory Control of antimicrobial therapy, in General Colle J, Barrie P, Andrew GF, Anthony $\mathrm{S}$, editors. Mackie and Mc Cartney Practical Medical Microbiology; 14th edition; New Delhi; 2007, 151-178.

11. Malik S, Gupta A, Singh KP, Agarwal J, Singh M. Antibiogram of Aerobic Bacterial Isolates from PostOperative wound Infections at a Tertiary Care Hospital in India. J. Infect. Dis-Antimicriob Agents. Jan-Apr-2011; 28; 45-51.

12. Afroz Z, Metri BC, Jyoti P. Bacteriological Profile and Antimicrobial Susceptibility Pattern of Skin and Soft Tissue Infections among Gram Negative Bacilli in a Tertiary Care Hospital of South India. J. Pharm. Scie \& Res. 2015, 7(7); 397-400.

13. Rao R, Sumathi S, Anuradha K, Venkatesh D, Krishna S. Bacteriology of Post Operative wound infections .Int. J. Pharm Biomed Res 2013, 4(2), 72-76.

14. Sowmya N, Savitha S, Mallive S, Mohanakrishnan K, Sumathi G, Arumugam P. A two year study of spectrum of bacterial isolates from wound infections by aerobic culture and their antibiotic pattern in a tertiary care centre. Int. J. Cure. Microbiol, App. Sci (2014) 3(8) 292-295.

15. Mehta VJ, Pandya JM, Mehta SJ, Surveillance of Post Operative wound infections in a Teaching Hospital, Gujarat. Int J Res Med. 2013; 2(4); 77-79.

16. Naik G, Srinivas R, Desphande. A Study on Surgical Site Infections caused by Staphylococcus aureus with a special search of Methicillin- Resistant isolates. Journal of Clinical and Diagnostic Research, 2011;5(3): 502-508.

17. Wanshi PS, Khan AQ, Ali S, Patil A. Analysis of Organisms Found at Incision site Intra-Operatively and its Implications with Post-Operative Infections. Int. J. of Sci and Res. Publications, 2014 Vol 4(4)

18. Anbumani N, Kalyani J, Mallika M. Prevalence of methicillin resistant Staphylococcus aureus in a tertiary referral hospital in Chennai, South India. Ind J Pract Doc 2006, 48 (4); 191-195.

19. Rajaduraipandi K, Mani KR, Pannerselvam K, M Mani, M Bhaskar, P Manikandan. Prevalence and antimicrobial pattern of methicillin resistant Staphylococcus aureus: A multicentre study. Ind J. Med. Micro 2006, 24(1): 34-38. 
20. Anupurba S, Sen MR, Nath G, Sharma BM, Gulati and Mohapatra TM. Prevalence of Methicillin Resistant Staphylococcus aureus in a Tertiary Referral Hospital in Uttar Pradesh, India J. of Medical microbiology 2003; 21 :49-51.

21. Shriyan A, Sheetal R, Nayak N .Aerobic micro-organisms in Post-Operative wound infections and their Antimicrobial suspceptibility Patterns. Journal of Clinical and Diagnostic Research 2010 December; 4; 3392-3396.

22. Javed FS, Reazvanian M, Kumar S, Norouzi $H$. Microbiological study of diabetic foot ulcer in an Indian
Tertiary Care Hospital. Int Journal of Life Sci and Review 2015:1(2); 65-70.

23. Amatya J, Rijal M, Baidya R. Bacteriological study of the Post Operative wound samples and antibiotic susceptibility pattern of the isolates in B\&B Hospital Lalitpur Nepal. JSM Microbiology 2015, 3(1): 1019.

24. Rai S, Yadav U N, Pant N D, Yakha J K, Tripathi PP, Poudel A, Lekhak B. Bacteriological Profile and Antimicrobial Susceptibility Patterns of Bacteria Isolated from Pus/Wound Swab Samples from Children Attending a Tertiary Care Hospital in Kathmandu, Nepal. International journal of Microbiology 2017: 1(6): 54-59

*Corresponding author:

Dr. UpasanaBhumbla, B-2, T-2, Geetanjali Staff Quarters, Geetanjali Medicity, Udaipur-313001 India

Email: ucupasana124@gmal.com

Financial or other Competing Interests: None. 